\title{
Analyses of C-Reactive Protein, Endothelial Nitric Oxide Synthase and Interleukin-6 Gene Polymorphisms in Adolescents with a Family History of Premature Coronary Artery Disease: A Pilot Study
}

\author{
Ataç Çelik ${ }^{1}$, Mustafa Özçetin ${ }^{2}$, Ömer Ateş$^{3}$, Fatih Altunkaş ${ }^{1}$, Kayıhan Karaman $^{1}$, İlker Akar ${ }^{4}$, İlker İnce ${ }^{4}$, \\ Murat Yalçın ${ }^{5}$, Metin Karayakalı ${ }^{1}$, Köksal Ceyhan ${ }^{1}$, Fatih Koç ${ }^{6}$ \\ 'Department of Cardiology, Gaziosmanpaşa University Faculty of Medicine, Tokat, Turkey \\ ${ }^{2}$ Department of Pediactics, Süleymaniye Obstetrics and Gynecology Training and Research Hospital, İstanbul, Turkey \\ ${ }^{3}$ Department of Medical Biology, Gaziosmanpaşa University Faculty of Medicine, Tokat, Turkey \\ ${ }^{4}$ Department of Cardiovascular Surgery, Gaziosmanpaşa University Faculty of Medicine, Tokat, Turkey \\ ${ }^{5}$ Department of Cardiology, GATA Haydarpaşa Military Hospital, İstanbul, Turkey \\ ${ }^{6}$ Department of Cardiology, Akdeniz University Faculty of Medicine, Antalya, Turkey
}

Background: Family history of premature atherosclerosis imposes a high risk to people. The relationship between atherosclerosis and gene polymorphisms of various biomarkers such as Endothelial Nitric Oxide Synthase (eNOS), C-Reactive Protein (CRP), and Interleukin-6 (IL-6) has shown in previous studies.

Aims: The major aim of the study was to evaluate the CRP, eNOS, and IL-6 gene polymorphisms in a group of adolescents who have a parental history of early coronary artery disease (CAD).

Study Design: Case-control study.

Methods: Thirty-six volunteers with a father with obstructive CAD during the first four decades and 46 subjects with a father with normal coronary arteries documented with coronary angiography were included in the study. Polymerase chain reaction-restriction fragment length polymorphism techniques were used to analyze CRP, eNOS, and IL-6 polymorphisms.

Results: We did not find any differences between the two groups with regard to age, sex, body mass index, renal functions, systolic and diastolic blood pressures, lipid profile, and fasting glucose, hemoglobin, and high sensitivity CRP. A significant difference was only observed in IL-6-572 G/C genotype distribution and allele frequency between two groups $(\mathrm{Pc}=0.036 \mathrm{OR}=3.48 \mathrm{CI}$ (95\%) 1.17-10.32).

Conclusion: The present study showed a significant association between the IL-6-572 G/C gene polymorphism (presence of $\mathrm{C}$ allele) and adolescents with a parental history of premature CAD.

Keywords: Atherosclerosis, C-reactive protein, polymorphism, nitric oxide synthase, interleukins
Cardiovascular disease is known to be the leading cause of death worldwide (1). Although the clinical complications of coronary artery disease (CAD) mainly occur in middle age, latest studies demonstrate that atherosclerosis begins in childhood (2). It was concluded that people with a parental history of early atherosclerosis are at high risk (3).
Recent studies have concluded that biomarkers such as C-reactive protein (CRP), endothelial nitric oxide synthase (eNOS), and interleukin-6 (IL-6) are associated with the progression and pathogenesis of atherosclerosis (4-6). The relationship with atherosclerosis has also shown for the related genes of these biomarkers $(7,8)$.

The present study was presented as poster presentation in XXIX. Ulusal Kardiyoloji Kongresi, Antalya, October 2013.

Address for Correspondence: Dr. Ataç Çelik, Department of Cardiology, Gaziosmanpaşa University Faculty of Medicine, Tokat, Turkey Phone: +90 5052936452 e-mail: dretaci@yahoo.com

Received: 05.02.2015 Accepted: 12.05.2015 • DOI: 10.5152/balkanmedj.2015.151190

Available at www.balkanmedicaljournal.org

Cite this article as:

Çelik A, Özçetin M, Ateș Ö, Altunkaş F, Karaman K, Akar İ, et al. Analyses of C-Reactive Protein, endothelial nitric oxide synthase and interleukin-6 gene polymorphisms in adolescents with a family history of premature coronary artery disease: a pilot study.

Balkan Med J 2015;32:397-402. 
It is mandatory to create noninvasive tools to understand early arterial disease and characterize increased cardiovascular risk in the young population (9). We have recently shown that carotis stiffness index but not pulse wave velocity and carotis intima-media thickness might be useful in order to examine subclinical atherosclerosis in adolescents with a parental history of premature CAD (10). The major aim of the present study was to evaluate the CRP, eNOS, and IL-6 gene polymorphisms in adolescents at risk because of their family history of premature CAD.

\section{MATERIALS AND METHODS}

\section{Study population}

The study population was enrolled from our pediatric outpatient clinic. We determined adolescents who have a father with a history of CAD. The fathers of 146 of these subjects had undergone coronary evaluation with angiography during the first four decades. All of the coronary angiograms belonging to fathers of the study subjects were visually reviewed. At least one coronary lesion $>2 \mathrm{~mm}$ in length and $>50 \%$ narrowing in diameter was defined as obstructive CAD. Of the 146 subjects, 62 refused to join to the study, 36 had a father with obstructive CAD, and 46 had a father with normal coronary arteries. One of the volunteers was a smoker and one was on anti-lipidemic therapy; they were excluded from the study.

The weight and height of the subjects were measured using a standardized technique; body mass index (BMI) was computed as body weight divided by the square of body height $\left(\mathrm{kg} / \mathrm{m}^{2}\right)$. Blood pressure was measured in subjects by one investigator using a validated protocol.

This study was performed in a single center. Study examinations were carried out by the cardiology and pediatric clinic. Ethics approval was obtained from the ethics committee at our institution and written informed consent was taken from the guardians of the volunteers.

\section{Biochemical analysis}

Blood samples for glucose level, high density lipoprotein cholesterol (HDL-C), triglycerides, low density lipoprotein cholesterol (LDL-C), and total cholesterol were obtained after 12 hours of fasting.

The high sensitivity CRP (hs-CRP) was measured by an immuno-turbidometric method (Cobas 6000, Roche Diagnostics, Mannheim, Germany) in our hospital laboratory. Volunteers with hs-CRP values over $8.6 \mathrm{mg} / \mathrm{L}$ were excluded from the analyses due to acute inflammation, as previously recommended (11).
TABLE 1. Primers and enzymes used for polymerase chain reaction

\begin{tabular}{llc}
\hline & Primers & $\begin{array}{c}\text { RFLP } \\
\text { Enzymes }\end{array}$ \\
\hline CRP & Forward 5'-CCCTTCAGTCCTAATGTCC-3' & HpyCH4 \\
+ 1444C/T & Reverse 5'-GCTCTTGCCTTATGAGTTTT-3' & III \\
NOS 3 & Forward 5'-TGGAGAGTCCTGGTGTACCCCA-3' & Msp I \\
-786 T/C & Reverse 5'-GCCTCCACCCCCACCCTGTC-3' & \\
IL-6 & Forward 5'-CGGTGAAGAATGGATGACCT-3' & Taq I \\
-1363G/T & Reverse 5'-AAACCAGACCCTTGCACAAC-3' & \\
IL-6 & Forward 5'-CAGCAGCCAACCTCCTCTAA-3' & Fok I \\
-597 G/A & Reverse 5'-CCAAGCCTGGGATTATGAAG-3' & \\
IL-6 & Forward 5'-CAGCAGCCAACCTCCTCTAA-3' & BsrB-I \\
-572 G/C & Reverse 5'-CCAAGCCTGGGATTATGAAG-3' & \\
IL-6 & Forward 5'TTGTCAAGACATGCCAAAGTGCGGAG-3' & BseL-I \\
-174 G/C & Reverse 5'-GTGCAATGTGACGTCCCTTAGCAT-3' & \\
IL-6 & Forward 5'-GCCAGTGATCCACAGAAACAA-3' & BstU-I \\
+ +2954G/C Reverse 5'-AGCTACTGGTGGCCAACGC-3' & \\
\hline $\begin{array}{l}\text { RFLP: restriction fragment length polymorphism; CRP: c-reactive protein; NOS: nitric } \\
\text { oxide synthase; IL-6: interleukin-6 }\end{array}$ &
\end{tabular}

\section{Molecular analysis}

DNA was isolated from venous blood samples. CRP $+1444 \mathrm{C} / \mathrm{T}$, NOS 3 -786T/C, IL-6 -1363G/T, IL-6 -597 G/A, IL-6 -572 G/C, IL-6 -174 G/C, and IL-6 +2954G/C polymorphisms were analyzed by the polymerase chain reactionrestriction fragment length polymorphism technique with the following primers and enzymes. (Table 1).

\section{Statistical analysis}

A validated statistical program was used to analyze variables (SPSS version 15.0, Chicago, IL, USA). The Kolmogorov-Smirnov test was used to define normality. The normally distributed independent variables between two groups were compared with two independent sample t-test and the non-normally distributed independent variables between two groups were compared with Mann-Whitney U Test. Non-normally distributed continuous data were presented as median and IQR [quartile 1 to quartile 3] and normally distributed continuous variables were expressed as mean \pm standard deviation (SD). A chi-square test was used to analyze the categorical data and expressed as numbers and percentages. $p$ values over 0.05 were accepted as statistically significant. Significant values were corrected with multiple testing (Bonferroni correction; Pc).

\section{RESULTS}

The age, sex, BMI, lipid profile, renal functions, systolic and diastolic blood pressures, fasting glucose, hemoglobin, 
TABLE 2. Baseline characteristics and laboratory findings of the study groups

\begin{tabular}{lccc}
\hline & $\begin{array}{c}\text { Control } \\
\text { group } \\
(\mathrm{n}=46)\end{array}$ & $\begin{array}{c}\text { Risky } \\
\text { group } \\
(\mathrm{n}=36)\end{array}$ & $\begin{array}{c}\mathrm{p} \\
\text { value }\end{array}$ \\
Variables & $13.91 \pm 1.31$ & $14.56 \pm 1.73$ & 0.060 \\
\hline Age (years) & $26(57)$ & $20(56)$ & 0.930 \\
Gender (Male) & $19.78 \pm 3.25$ & $20.29 \pm 3.59$ & 0.500 \\
Body mass index $\left(\mathrm{kg} / \mathrm{m}^{2}\right)$ & $111.85 \pm 12.75$ & $113.31 \pm 14.73$ & 0.633 \\
Systolic blood pressure (mmHg) & $69.46 \pm 8.11$ & $72.44 \pm 9.10$ & 0.121 \\
Diastolic blood pressure (mmHg) & $8.20 \pm 2.71$ & $7.71 \pm 2.43$ & 0.450 \\
White blood cell (x10 $/ \mathrm{iL})$ & $12.35 \pm 0.85$ & $12.31 \pm 1.25$ & 0.899 \\
Hemoglobin $(\mathrm{g} / \mathrm{dL})$ & $87.63 \pm 9.91$ & $90.27 \pm 9.19$ & 0.275 \\
Fasting glucose $(\mathrm{mg} / \mathrm{dL})$ & $0.49 \pm 0.11$ & $0.51 \pm 0.13$ & 0.644 \\
Creatinine $(\mathrm{mg} / \mathrm{dL})$ & $3.25 \pm 0.72$ & $3.36 \pm 1.10$ & 0.649 \\
Uric acid $(\mathrm{mg} / \mathrm{dL})$ & $156.76 \pm 27.62$ & $165.12 \pm 35.60$ & 0.403 \\
Total cholesterol $(\mathrm{mg} / \mathrm{dL})$ & $112.35 \pm 55.16$ & $104.91 \pm 48.44$ & 0.626 \\
Triglyceride $(\mathrm{mg} / \mathrm{dL})$ & $84.23 \pm 22.26$ & $93.76 \pm 32.30$ & 0.282 \\
LDL-C (mg/dL) & $63.65 \pm 13.41$ & $56.55 \pm 14.95$ & 0.106 \\
HDL-C (mg/dL) & $7.00 \pm 3.10$ & $6.76 \pm 5.65$ & 0.874 \\
Erythrocyte sedimentation & & & \\
rate (mm/h) & $0.46[0.24-1.62]$ & $0.36[0.23-0.75]$ & 0.582 \\
hs-CRP (mg/L) & & & \\
\hline
\end{tabular}

LDL-C: low-density lipoprotein cholesterol; HDL: high-density lipoprotein cholesterol; hs-CRP: high sensitivity C-reactive protein

Data are shown as $\mathrm{n}(\%)$, mean $\pm \mathrm{SD}$, and median [IQR].

TABLE 3. Distribution of genotype and allele frequencies and odds ratios and $95 \%$ confidence intervals of the atherosclerosis risk among CRP, eNOS, and

\begin{tabular}{|c|c|c|c|c|}
\hline \multicolumn{5}{|c|}{ IL-6 polymorphisms } \\
\hline Locus & $\begin{array}{l}\text { Control } \\
\text { group } \\
(n=46)\end{array}$ & $\begin{array}{l}\text { Risky } \\
\text { group } \\
(\mathrm{n}=36)\end{array}$ & $\begin{array}{l}\mathrm{p}(\mathrm{Pc}) \\
\text { value }\end{array}$ & $\begin{array}{l}\text { Odds ratios } \\
\text { (CI) } 95 \%\end{array}$ \\
\hline \multicolumn{5}{|l|}{$\mathrm{CRP}+1444 \mathrm{C} / \mathrm{T}$} \\
\hline Genotypes & & & 0.585 & \\
\hline $\mathrm{C} / \mathrm{C}$ & $24(52.2)$ & $16(44.4)$ & & \\
\hline $\mathrm{C} / \mathrm{T}$ & $19(41.3)$ & $19(52.8)$ & & \\
\hline $\mathrm{T} / \mathrm{T}$ & $3(6.5)$ & $1(2.8)$ & & \\
\hline Alleles & & & 0.390 & $1.10(0.56-2.18)$ \\
\hline $\mathrm{C}$ & $67(72.8)$ & $51(70.8)$ & & \\
\hline $\mathrm{T}$ & $25(27.2)$ & $21(29.2)$ & & \\
\hline eNOS -786 T/C & & & 0.502 & \\
\hline \multicolumn{5}{|l|}{ Genotypes } \\
\hline $\mathrm{T} / \mathrm{T}$ & $28(60.9)$ & $18(50.0)$ & & \\
\hline $\mathrm{T} / \mathrm{C}$ & $11(23.9)$ & $13(36.1)$ & & \\
\hline $\mathrm{C} / \mathrm{C}$ & $7(15.2)$ & $5(13.9)$ & & \\
\hline Alleles & & & 0.255 & $1.26(0.64-2.46)$ \\
\hline $\mathrm{T}$ & $67(72.8)$ & $49(68.1)$ & & \\
\hline $\mathrm{C}$ & $25(27.2)$ & $23(31.9)$ & & \\
\hline IL-6 -1363 G/T & & & 0.924 & \\
\hline \multicolumn{5}{|l|}{ Genotypes } \\
\hline $\mathrm{G} / \mathrm{G}$ & $41(89.1)$ & $32(88.8)$ & & \\
\hline $\mathrm{G} / \mathrm{T}$ & $4(8.7)$ & $4(11.1)$ & & \\
\hline
\end{tabular}

TABLE 3. Continued

\begin{tabular}{ccccc}
\hline T/T & $1(2.2)$ & $0(0.0)$ & & \\
Alleles & & & 0.408 & $0.84(0.23-3.08)$ \\
G & $86(93.5)$ & $68(94.4)$ & & \\
T & $6(6.5)$ & $4(5.6)$ & & \\
IL-6 -597 G/A & & & 0.922 & \\
Genotypes & & & & \\
G/G & $29(63.0)$ & $24(66.6)$ & & \\
G/A & $15(32.6)$ & $11(30.5)$ & & \\
A/A & $2(4.3)$ & $1(2.8)$ & & \\
Alleles & & & 0.343 & $0.85(0.39-1.85)$ \\
G & $73(79.3)$ & $59(81.9)$ & & \\
A & $19(20.7)$ & $13(18.1)$ & & \\
IL-6 -572 G/C & & & 0.012 & \\
Genotypes & & & $(0.036)$ & \\
G/G & $42(91.3)$ & $25(69.4)$ & & \\
G/C & $3(6.5)$ & $10(27.8)$ & & \\
C/C & $1(2.2)$ & $1(2.8)$ & & \\
Alleles & & & 0.012 & $3.48(1.17-10.32)$ \\
G & $87(94.5)$ & $60(83.3)$ & $(0.024)$ & \\
C & $5(5.4)$ & $12(16.6)$ & & \\
IL-6 -174 G/C & & & 0.949 & \\
Genotypes & & & & \\
G/G & $29(63.0)$ & $24(66.6)$ & & \\
G/C & $16(34.8)$ & $12(33.3)$ & & \\
C/C & $1(2.2)$ & $0(0.0)$ & & \\
Alleles & & & $0.11-3.49)$ \\
G & $74(80.4)$ & $60(83.3)$ & & \\
C & $18(19.6)$ & $12(16.6)$ & & \\
IL-6 +2954 G/C & & & $0.314-1.83)$ \\
Genotypes & & & & \\
G/G & $42(91.3)$ & $34(94.4)$ & & \\
G/C & $4(8.7)$ & $2(5.6)$ & & \\
C/C & $0(0)$ & $0(0.0)$ & & \\
G & & & & \\
C & & & & \\
\hline
\end{tabular}

CRP: C-reactive protein; NOS: nitric oxide synthase; IL-6: interleukin-6

Data are shown as $n(\%)$, Pc Bonferroni correction.

erythrocyte sedimentation rate, and hs-CRP levels were not different between the two groups (Table 2).

A significant difference was observed only in IL-6 -572 G/C genotype distribution and allele frequency between the two groups $(\mathrm{Pc}=0.036)$. Differences between the other genotypes remained insignificant (Table 3 ).

\section{DISCUSSION}

The major finding of the study was that there is a significant association with the $\mathrm{C}$ allele of the IL-6-572 G/C gene 
polymorphism and adolescents with a parental history of premature CAD.

Family history of CAD is a risk factor for cardiovascular disease (12). It is known that a 2 -fold increase in risk for cardiovascular disease with a positive history of premature CAD (3). The development of CAD becomes more important in subjects who are genetically at risk, especially in younger ages. Although family history is a strong risk factor, there are also other risk factors. Hypertension, dyslipidemia, obesity, diabetes mellitus or smoking habit may also contribute to risk of CAD development. None of the subjects in our study had these risk factors. The absence of these risk factors may lead to a lower risk of atherosclerosis development. Although it is difficult to expect CAD in these subjects with only risk factors in a multifactorial disease such as atherosclerosis, showing this risk genetically will provide an advantage. Recently, genetic polymorphism studies about inflammation biomarkers that are playing a role in the pathogenesis of atherosclerosis were performed. In the study of Ciftdogan et al. (13), the prothrombin G20210A and factor V G1691A polymorphisms were found at higher frequencies in child with a family history of premature CAD. Our findings for the IL-6-572 G/C polymorphism are compatible with the previous results and have originality in terms of being related with IL- 6 which is a marker of inflammation.

Inflammation has a major critical role in the atherosclerosis process. As an inflammatory marker, CRP levels are associated with CAD (4-6). It has been concluded that genetic variations are responsible for the almost $35-40 \%$ difference in CRP levels between subjects (14). Brull et al. (15) showed that the $+1444 \mathrm{C} / \mathrm{T}$ gene polymorphism in the 3'UTR significantly affects CRP levels. There are also many studies indicating that polymorphisms in the CRP gene were associated with CAD (16-19). Moreover, Abd El-Aziz et al. (19) showed that hs$\mathrm{CRP}$ levels and the presence of the $\mathrm{CRP}+1059 \mathrm{G}>\mathrm{C}$ polymorphism are the determinants of premature atherosclerosis. In the present study, we found no association between the CRP $+1444 \mathrm{C} / \mathrm{T}$ polymorphism and adolescents at risk of premature atherosclerosis. The main reason for this discordance is the difference in the study populations. While previous studies investigated CRP polymorphism in patients with CAD, we studied healthy subjects with a family history of premature atherosclerosis. When viewed from this perspective, our findings were original.

IL-6 is one of the other proinflammatory cytokines which is associated with CAD. The genetic changes related to IL-6 might lead to cardiovascular diseases $(20,21)$. It has been concluded that the $174 \mathrm{G} / \mathrm{C}$ polymorphism of the IL- 6 gene effects IL-6 production (22). Of the three studies evaluating the relationship between premature CAD and the IL-6 poly- morphism, only one did not find any significant association (23-25). Because our study group was composed of healthy volunteers instead of patients with premature $\mathrm{CAD}$, our findings regarding the IL-6-572 G/C polymorphism were original.

Nitric oxide is a potent vasodilator originating from endothelial cells and it has a regulatory role in the regulation of blood pressure. There are many studies showing significant or insignificant associations between the eNOS gene polymorphism and premature CAD (26-29). Ekmekci et al. concluded that the eNOS $4 \mathrm{a} / \mathrm{b}$ gene polymorphism was significantly higher in ST elevation myocardial infarction patients, but this polymorphism was not found to be an independent predictor for aortic dissection $(27,29)$. Unfortunately, Milutinović et al. did not show the eNOS $4 \mathrm{a} / \mathrm{b}$ gene polymorphism to be a genetic marker for premature CAD (26). Cam et al. (28) found an association between the eNOS Glu298Asp polymorphism and premature CAD. Unlike previous studies, our subjects were healthy adolescents.

The small sample size is the major limitation of the present study. It is obvious that finding healthy adolescent subjects who have a father with obstructive CAD during the first four decades is pretty difficult and time consuming. In a previous genetic polymorphism study with a similar population to ours (children aged between 5-16 years family history of premature CAD), the case group was formed of only 72 subjects (13). Although our sample size was small, a significant difference still existed for the IL-6 -572 G/C gene polymorphism, even after Bonferroni correction test was applied. High-volumed studies in this area will be more informative. As a limitation, we did not measured serum levels of eNOS and IL-6. It would be challenging to evaluate the possible correlation between the serum levels and genetic polymorphisms of these biomarkers. It is known that genetic information has an equal chance of being transmitted from the father and mother. Unfortunately, however, this was not taken into consideration when planning the study.

In conclusion, there is an independent association between the IL- 6 gene polymorphism and adolescents with a family history of premature CAD. High-volume studies evaluating polymorphisms are needed in order to predict possible early phase atherosclerosis in this subgroup of the population.

Ethics Committee Approval: Ethics committee approval was received for this study from the ethics committee of the institution. (Approval Number: 11-BADK-034).

Informed Consent: Written informed consent was obtained from patients' relatives who participated in this study.

Peer-review: Externally peer-reviewed.

Author contributions: Concept - A.Ç., M.Ö., Ö.A., F.K.; Design - A.Ç., M.Ö., F.A., M.Y.; Supervision - A.Ç., Ö.A., K.K., İ.A., M.Y., 
F.K.; Resource - A.Ç., Ö.A., İ.İ., M.K., K.C.; Materials - A.Ç., F.A., İ.İ., M.K., K.C.; Data Collection \&/or Processing - A.Ç., M.Ö., F.A., M.K.; Analysis \&/or Interpretation - A.Ç., M.Ö., K.K., İ.A., M.Y., K.C., F.K.; Literature Search - A.Ç., K.K., İ.A., İ.İ.; Writing - A.Ç., Ö.A.; Critical Reviews - A.Ç., M.Ö., Ö.A., F.A., K.K., İ.A., İ.İ., M.Y., M.K., K.C., F.K.

Conflict of Interest: No conflict of interest was declared by the authors.

Financial Disclosure: This study was funded by Gaziosmanpaşa University Scientific Research Projects (2011/90).

\section{REFERENCES}

1. Najjar SS, Scuteri A, Lakatta EG. Arterial aging: is it an immutable cardiovascular risk factor? Hypertension 2005;46:454-62. [CrossRef]

2. Stary HC. Evolution and progression of atherosclerotic lesions in coronary arteries of children and young adults. Arteriosclerosis 1989;9:I19-32.

3. De Backer G, Ambrosioni E, Borch-Johnsen K, Brotons C, Cifkova R, Dallongeville J, et al; European Society of Cardiology Committee for Practice Guidelines. Third Joint Task Force of European and Other Societies on Cardiovascular Disease Prevention in Clinical Practice. European guidelines on cardiovascular disease prevention in clinical practice. Third Joint Task Force of European and Other Societies on Cardiovascular Disease Prevention in Clinical Practice. Eur Heart J 2003;24:160110. [CrossRef]

4. Virani SS, Polsani VR, Nambi V. Novel markers of inflammation in atherosclerosis. Curr Atheroscler Rep 2008;10:164-70. [CrossRef]

5. Kampoli AM, Tousoulis D, Antoniades C, Siasos G, Stefanadis C. Biomarkers of premature atherosclerosis. Trends $\mathrm{Mol} \mathrm{Med}$ 2009; 15:23-32. [CrossRef]

6. Tousoulis D, Kampoli AM, Papageorgiou N, Androulakis E, Antoniades C, Toutouzas K, et al. Pathophysiology of atherosclerosis: the role of inflammation. Curr Pharm Des 2011;17:4089110. [CrossRef]

7. Mani A, Radhakrishnan J, Wang H, Mani A, Mani MA, NelsonWilliams C, et al. LRP6 mutation in a family with early coronary disease and metabolic risk factors. Science 2007;315:1278-82. [CrossRef]

8. Mayer B, Erdmann J, Schunkert H. Genetics and heritability of coronary artery disease and myocardial infarction. Clin Res Cardiol 2007;96:1-7. [CrossRef]

9. Urbina EM, Williams RV, Alpert BS, Collins RT, Daniels SR, Hayman L, et al; for the American Heart Association Atherosclerosis, Hypertension and Obesity in Youth Committee of the Council on Cardiovascular Disease in the Young. Noninvasive assessment of subclinical atherosclerosis in children and adolescents: recommendations for standard assessment for clinical research: a scientific statement from the American Heart Association. Hypertension 2009;54:919-50. [CrossRef]

10. Celik A, Ozcetin M, Celikyay ZR, Sogut E, Yerli Y, Kadi H, et al. Evaluation of possible subclinical atherosclerosis in adolescents with a family history of premature atherosclerosis. Atherosclerosis 2012;222:537-40. [CrossRef]

11. McDade TW, Hawkley LC, Cacioppo JT. Psychological and behavioral predictors of inflammation in middle-aged and older adults: The Chicago Health, Aging, and Social Relations Study. Psychosom Med 2006;68:376-81. [CrossRef]

12. Andresdottir MB, Sigurdsson G, Sigvaldason H, Gudnason V. Fifteen percent of myocardial infarctions and coronary revascularizations explained by family history unrelated to conventional risk factors. The Reykjavik Cohort Study. Eur Heart J 2002;23:1655-63. [CrossRef]

13. Ciftdogan DY, Coskun S, Ulman C, Tikiz H. The factor V G1691A, factor V H1299R, prothrombin G20210A polymorphisms in children with family history of premature coronary artery disease. Coron Artery Dis 2009;20:435-9. [CrossRef]

14. Yan M, Zhao L, Zheng F, Sun X, Zhang Y, Wang C. The relationship between gene polymorphism and CRP level in a Chinese Han population. Biochem Genet 2007;45:1-9. [CrossRef]

15. Brull DJ, Serrano N, Zito F, Jones L, Montgomery HE, Rumley A, et al. Human CRP gene polymorphism influences CRP levels: implications for the prediction and pathogenesis of coronary heart disease. Arterioscler Thromb Vasc Biol 2003;23:2063-9. [CrossRef]

16. Wang L, Lu X, Li Y, Li H, Chen S, Gu D. Functional analysis of the C-reactive protein (CRP) gene $-717 \mathrm{~A}>\mathrm{G}$ polymorphism associated with coronary heart disease. BMC Med Genet 2009;10:73. [CrossRef]

17. Akbarzadeh Najar R, Ghaderian SM, Tabatabaei Panah AS. Creactive protein(CRP) gene polymorphisms: implication in CRP plasma levels and susceptibility to acute myocardial infarction. Mol Biol Rep 2012;39:3705-12. [CrossRef]

18. Hermann M, Fischer D, Hoffmann MM, Gasser T, Quitzau $\mathrm{K}$, Meinertz T, et al. CRP and CD14 polymorphisms correlate with coronary plaque volume in patients with coronary artery disease--IVUS substudy of the ENCORE trials. Atherosclerosis 2012;220:172-6. [CrossRef]

19. Abd El-Aziz TA, Mohamed RH. Human C-reactive protein gene polymorphism and metabolic syndrome are associated with premature coronary artery disease. Gene 2013;532:216-21. [CrossRef]

20. Giacconi R, Cipriano C, Albanese F, Boccoli G, Saba V, Olivieri F, et al. The $174 \mathrm{G} / \mathrm{C}$ polymorphism of IL-6 is useful to screen old subjects at risk for atherosclerosis or to reach successful ageing. Exp Gerontol 2004;39:621-8. [CrossRef]

21. Brull DJ, Montgomery HE, Sanders J, Dhamrait S, Luong L, Rumley A, et al. Interleukin-6 gene $-174 \mathrm{G} / \mathrm{C}$ and $-572 \mathrm{G} / \mathrm{C}$ promoter polymorphisms are strong predictors of plasma interleukin-6 levels after coronary artery bypass surgery. Arterioscler Thromb Vasc Biol 2001;21:1458-63. [CrossRef]

22. Aker S, Bantis C, Reis P, Kuhr N, Schwandt C, Grabensee B, et al. Influence of interleukin-6 G-174C gene polymorphism 
on coronary artery disease, cardiovascular complications and mortality in dialysis patients. Nephrol Dial Transplant 2009;24:2847-51. [CrossRef]

23. Phulukdaree A, Khan S, Ramkaran P, Govender R, Moodley D, Chuturgoon AA. The interleukin-6 -147 g/c polymorphism is associated with increased risk of coronary artery disease in young South African Indian men. Metab Syndr Relat Disord 2013;11:205-9. [CrossRef]

24. Maitra A, Shanker J, Dash D, John S, Sannappa PR, Rao VS, et al. Polymorphisms in the IL6 gene in Asian Indian families with premature coronary artery disease--the Indian Atherosclerosis Research Study. Thromb Haemost 2008;99:944-50. [CrossRef]

25. Sekuri C, Cam FS, Sagcan A, Ercan E, Tengiz I, Alioglu E, et al. No association of interleukin- 6 gene polymorphism $(-174$ $\mathrm{G} / \mathrm{C}$ ) with premature coronary artery disease in a Turkish cohort. Coron Artery Dis 2007;18:333-7. [CrossRef]
26. Milutinović A, Hruskovicova $\mathrm{H}$. The eNOS gene polymorphism does not have a major impact on lipid parameters and premature coronary artery disease in Slovene men (Caucasians). Folia Biol (Praha) 2005;51:47-9.

27. Ekmekçi A, Uluganyan M, Gungör B, Abacı N, Ozcan KS, Ertaş $\mathrm{G}$, et al. Association between endothelial nitric oxide synthase intron $4 \mathrm{a} / \mathrm{b}$ polymorphism and aortic dissection. Turk Kardiyol Dern Ars 2014;42:55-60. [CrossRef]

28. Cam SF, Sekuri C, Tengiz I, Ercan E, Sagcan A, Akin M, et al. The G894T polymorphism on endothelial nitric oxide synthase gene is associated with premature coronary artery disease in a Turkish population. Thromb Res 2005;116:287-92. [CrossRef]

29. Ekmekçi A, Ozcan KS, Güngör B, Abaci N, Osmonov D, Zencirci A, et al. The relationship between endothelial nitric oxide synthase $4 \mathrm{a} / 4 \mathrm{~b}$ gene polymorphism and premature coronary artery disease. Acta Cardiol 2013;68:464-8. 